\title{
Identification of genes related to learning and memory in the brain transcriptome of the mollusc, Hermissenda crassicornis
}

\author{
Arianna N. Tamvacakis, Adriano Senatore, and Paul S. Katz \\ Neuroscience Institute, Georgia State University, Atlanta, Georgia 30302-4010, USA
}

\begin{abstract}
The sea slug Hermissenda crassicornis (Mollusca, Gastropoda, Nudibranchia) has been studied extensively in associative learning paradigms. However, lack of genetic information previously hindered molecular-level investigations. Here, the Hermissenda brain transcriptome was sequenced and assembled de novo, producing 165,743 total transcripts. Orthologs of 95 genes implicated in learning were identified. These included genes for a serotonin receptor and a GABA-B receptor subunit that had not been previously described in molluscs, as well as an adenylyl cyclase gene not previously described in gastropods. This study illustrates the Hermissenda transcriptome's potential as an important genetic tool in future learning and memory research.
\end{abstract}

[Supplemental material is available for this article.]

Nervous systems of molluscs have been a focus of neuroscience research for many decades, yet their study has been impeded by lack of genetic information. The nudibranch Hermissenda crassicornis exhibits a simple form of associative learning, which has been studied extensively: it can learn to associate light changes with vestibular stimulation (Crow and Alkon 1978). The neural correlates of Hermissenda's associative memories formed during lightmovement pairings have been uncovered (Alkon 1980; Crow and Alkon 1980; Britton and Farley 1999; Tamse et al. 2003; Cavallo et al. 2014). Hermissenda has also been the subject of investigations related to many other aspects of neuroscience, including sensory and motor neuron physiology (Crow and Tian 2004; Nesse and Clark 2010; Jin and Crow 2011; Crow et al. 2013) and the evolution of behaviors and neurotransmitter systems (Lillvis et al. 2012; Newcomb et al. 2012; Lillvis and Katz 2013). A limited number of molecular-level studies have been performed on Hermissenda in these areas (Nelson and Alkon 1988; Crow et al. 1997). Broader-scale genetic experiments, such as identification of genes or specific genetic isoforms that produce proteins involved in Hermissenda associative learning, have been impossible without more extensive genetic information specifically from Hermissenda.

Transcriptomes have been sequenced in a small number of other gastropod species, including neuronal transcriptomes from Aplysia californica (Moroz et al. 2006; Fiedler et al. 2010; Heyland et al. 2011), A. kurodai (Lee et al. 2008; Choi et al. 2010), Lymnaea stagnalis (Bouetard et al. 2012; Sadamoto et al. 2012), and Tritonia diomedea (Senatore et al. 2015), which have been used in studies of learning and other aspects of neuroscience. The field of molluscan neurogenomics is growing thanks in large part to recent advances in sequencing technologies, which allow larger amounts of transcriptomic information to be sequenced at lower costs compared with technologies available a few years ago.

In this study, we describe the brain transcriptome of the sea slug Hermissenda crassicornis. The transcriptome was sequenced from central nervous system tissue mRNA, which included the cerebropleural ganglia, pedal ganglia, optic ganglia, eyes, and sta-

\section{Corresponding author: pkatz@gsu.edu}

Article is online at http://www.learnmem.org/cgi/doi/10.1101//m.038158. 115. tocyst hair cells. Shotgun de novo assembly generated 165,743 total transcripts. To illustrate its usefulness as a genetic tool, we have identified orthologs of genes related to learning and memory from the Hermissenda transcriptome, including genes that were not previously identified in molluscs.

Paired-end sequencing of Hermissenda mRNA generated 109M 100-bp reads. Low-quality reads were trimmed using Sickle (Joshi and Fass 2011), and reads were assembled by de novo assembly using Trinity (Haas et al. 2013). The 165,743 total transcripts, or contigs, were grouped in the assembly into 99,944 Trinity Chrysalis components (e.g., comp1, comp2, etc.) and 115,126 Trinity Butterfly components (e.g., comp1_c0, comp1_c1 etc.). We consider the Chrysalis components as the completely nonredundant transcript groupings, since Butterfly components originated from Chrysalis-derived De Bruijn graphs, some of which subsequently partitioned during Butterfly due to low read support (Haas et al. 2013). The average contig length of the Hermissenda transcriptome was $778.81 \mathrm{bp}$ (Table 1). The largest contig was 35,109 bp in length. Proteins were predicted in silico by TransDecoder. More than half of the predicted proteins with complete open reading frames (ORFs) were 300 amino acids (aa) or longer, indicating that the transcriptome assembly contains a large number of genes coding for full-length proteins (Supplemental Fig. S1A). Of the total number of TransDecoder-predicted proteins, 4912 proteins were complete, 3515 were missing the $5^{\prime}$ end, 1851 were missing the $3^{\prime}$ end, and 5404 were missing both the $5^{\prime}$ and $3^{\prime}$ ends (Supplemental Fig. S1A, inlay).

To compare the Hermissenda brain transcriptome with previously published genetic information, BLAST searches were run against published data sets. Matching components were then filtered to select the best hit per component (BHPC). The Hermissenda transcriptome yielded 20,152 nonredundant BHPC matches with $E$-values below $1 \times 10^{-6}$ by tBLASTx (i.e., protein-

(C) 2015 Tamvacakis et al. This article is distributed exclusively by Cold Spring Harbor Laboratory Press for the first 12 months after the full-issue publication date (see http://learnmem.cshlp.org/site/misc/terms.xhtml). After 12 months, it is available under a Creative Commons License (AttributionNonCommercial 4.0 International), as described at http://creativecommons. org/licenses/by-nc/4.0/. 
Table 1. Hermissenda crassicornis brain transcriptome assembly statistics. The de novo assembly of trimmed reads. (A) Transcriptome size and content. (B) Contig size and quality based on entire assembled transcriptome, or (C) based on longest isoform per component.

\begin{tabular}{lr} 
(A) Description of transcripts & \\
Total transcripts & 165,743 \\
Total Chrysalis components & 99,944 \\
Total Butterfly components & 115,126 \\
Percent GC & 39.51 \\
(B) Based on all transcripts (bp) & 389 \\
Median contig length & 778.1 \\
Average contig & $128,965,468$ \\
Total assembled bases & 4851 \\
Contig N $N_{10}$ & 3341 \\
Contig $N_{20}$ & 2483 \\
Contig $N_{30}$ & 1880 \\
Contig $N_{40}$ & 1400 \\
Contig $N_{50}$ & \\
(C) Based on longest isoform per subcomponent (bp) & 329 \\
Median contig length & 604.5 \\
Average contig & $69,593,541$ \\
Total assembled bases & 3831 \\
Contig $N_{10}$ & 2566 \\
Contig $N_{20}$ & 1842 \\
Contig $N_{30}$ & 1300 \\
Contig $N_{40}$ & 903 \\
Contig $N_{50}$ & \\
\hline
\end{tabular}

level alignment) against a database created from $T$. diomedea brain transcriptome mRNA and 16,995 matches against an A. californica mRNA data set (Supplemental Fig. S1B). The invertebrate RefSeq protein data set matched the highest number of Hermissenda translated nucleotide transcripts, compared with mammalian and nonmammalian vertebrate RefSeq protein data sets, as well as the SwissProt protein data set (Supplemental Fig. S1C). These BLAST results indicate that the Hermissenda transcriptome is complete in its genetic coverage relative to other published transcriptome assemblies.

Using translated protein BLAST results from the comparison with the SwissProt protein data set, components were filtered to remove hits with $E$-values of $1 \times 10^{-3}$ or greater, in order to remove matches made by chance alone. The 12,081 resulting transcripts were subsequently uploaded to BLAST2GO (Conesa et al. 2005), which used a cutoff value of $1 \times 10^{-6}$ to infer homology with SwissProt database sequences, followed by InterProScan, GO-SLIM, and Enzyme Code Mapping. The resulting 8916 genes were assigned gene ontology (GO) terms (Ashburner et al. 2000). GO assignments were generated for each of the three major GO branches at BLAST2GO Level 2: molecular function, biological process, and cellular component (Supplemental Fig. S2A). GO terms were similar at level 2 compared with the previously published L. stagnalis (Sadamoto et al. 2012) and T. diomedea (Senatore et al. 2015) assemblies.

Using the Kyoto Encyclopedia of Genes and Genomes (KEGG) (Kanehisa and Goto 2000), enzymatic pathways were mapped via BLAST2GO-KEGG: 103 biological pathways were identified. These pathways incorporated 1143 transcriptome sequences, including 579 enzyme sequences. Seventeen pathways were identified as containing one or more enzymes related to learning (Supplemental Fig. S2C). Together, these analyses indicate that the Hermissenda transcriptome contains a large amount of genetic information, meaning that it can be used as a new tool in the study of molluscan learning.

Several intracellular mechanisms have been identified as mediating light-turbulence associative learning in Hermissenda. Hair cells activated by turbulence release $\gamma$-aminobutyric-acid (GABA) through a mechanism mediated by adenylyl cyclase (AC), protein kinase A (PKA), and calcium (Alkon et al. 1993; Tamse et al. 2003). GABA release activates type B photoreceptor metabotropic GABA receptors, and when paired with light stimulation enhances photoreceptor response. Serotonin (5-HT) stimulation from interneurons paired with light also enhances photoreceptor responses. Within the photoreceptors, the light-turbulence pairing and subsequent GABA and 5-HT release activates pathways involving IP3/DAG, protein kinase C (PKC), and mitogen activated protein kinase (MAPK), and elevation of arachidonic acid (AA) (Supplemental Fig. S3). This leads to an increase in calcium within photoreceptors, which amplifies their excitability and is a correlate of memory storage (Blackwell 2006; Blackwell and Farley 2008). The specific genes underlying these protein interactions have not, however, been identified previously in Hermissenda. We have used the proposed model for Hermissenda associative learning as a basis to identify genes that code for proteins related to these changes (Supplemental Table S1), and have highlighted three categories of genes using phylogenetic analyses here.

5-HT modulates Hermissenda photoreceptors and interneurons during paired light and turbulence associative learning (Jin et al. 2009). Therefore, we investigated 5-HT receptor genes in Hermissenda. Four families of 5-HT receptor genes (families 1, 2, 4 , and 7) had been previously identified in molluscs (Nagakura et al. 2010), and a fifth family (family 6) had been predicted from the Aplysia genome (XP_005105784.1). The 5-HT1 gene has undergone a duplication event in molluscs, resulting in 5-HT1a and 5-HT1b receptors (Nagakura et al. 2010). No 5-HT receptor genes had been previously identified in Hermissenda or other Nudibranchs.

The Hermissenda brain transcriptome revealed putative orthologs of each of the previously identified receptor genes, 5 -HT1a, -1b, -2, -4, and -7. It also uncovered a 5-HT6 ortholog, which had previously not been identified as expressed from mRNA in any invertebrate, to our knowledge. A maximum likelihood phylogenetic tree shows that all of the families cluster with other known receptor genes (Fig. 1A). As previously shown, 5-HT2 receptors clustered with dopamine D2 receptors, whereas 5-HT6 genes were more closely related to dopamine D1 receptors (Mustard et al. 2005; Nagakura et al. 2010; Spielman et al. 2015).

We confirmed the existence of the 5-HT6 gene in the Aplysia (aplysiagenetools.org) and Tritonia brain transcriptomes. DNA plasmids were generated by three or more independent PCR reactions, followed by cloning to pGEM-T Easy vectors. Each plasmid was sequenced, and sequences were aligned using ClustalW to verify that sequence identity matched between the transcriptomes and the cDNA. Hermissenda 5-HT 1a, 1b, 4, 6, and 7 receptor genes were sequenced. Tritonia 5 -HT 1a, 1b, 4, 6, and 7 receptor genes were also sequenced. The resulting PCR-generated DNA sequences were $\sim 98 \%$ identical to the transcriptome sequences by ClustalW alignment (data not shown).

The transcriptome also contained a novel isoform of the 5-HT2 family, referred to here as 5-HT2b. The previously identified molluscan 5-HT2 type gene will be referred to as 5-HT2a here. The 5-HT2 $\mathrm{b}_{\text {Herm }}$ gene fragment predicted a 335 amino acidlong protein containing transmembrane domains $1-5$, only, and aligned by BLAST to arthropod 5-HT2 b receptors. The 5-HT2 $\mathrm{a}_{\text {Herm }}$ gene was fragmented between two contigs: comp74520_c0_seq1 predicted a 314 amino acid protein containing transmembrane domains 1-5, while comp77190_c0_seq1 predicted a 383 amino acid protein, which coded for intracellular loop 5 and transmembrane domains 6-7. To our knowledge, 5-HT2b has not been previously identified in any other mollusc. To be assured that the gene is molluscan, we identified 5-HT2b homologs using BLAST searches in the Aplysia (aplysiagenetools.org) and Tritonia brain transcriptomes. Phylogenetic analysis and BLAST comparisons revealed that the molluscan $2 \mathrm{~b}$ receptor clustered more closely with 


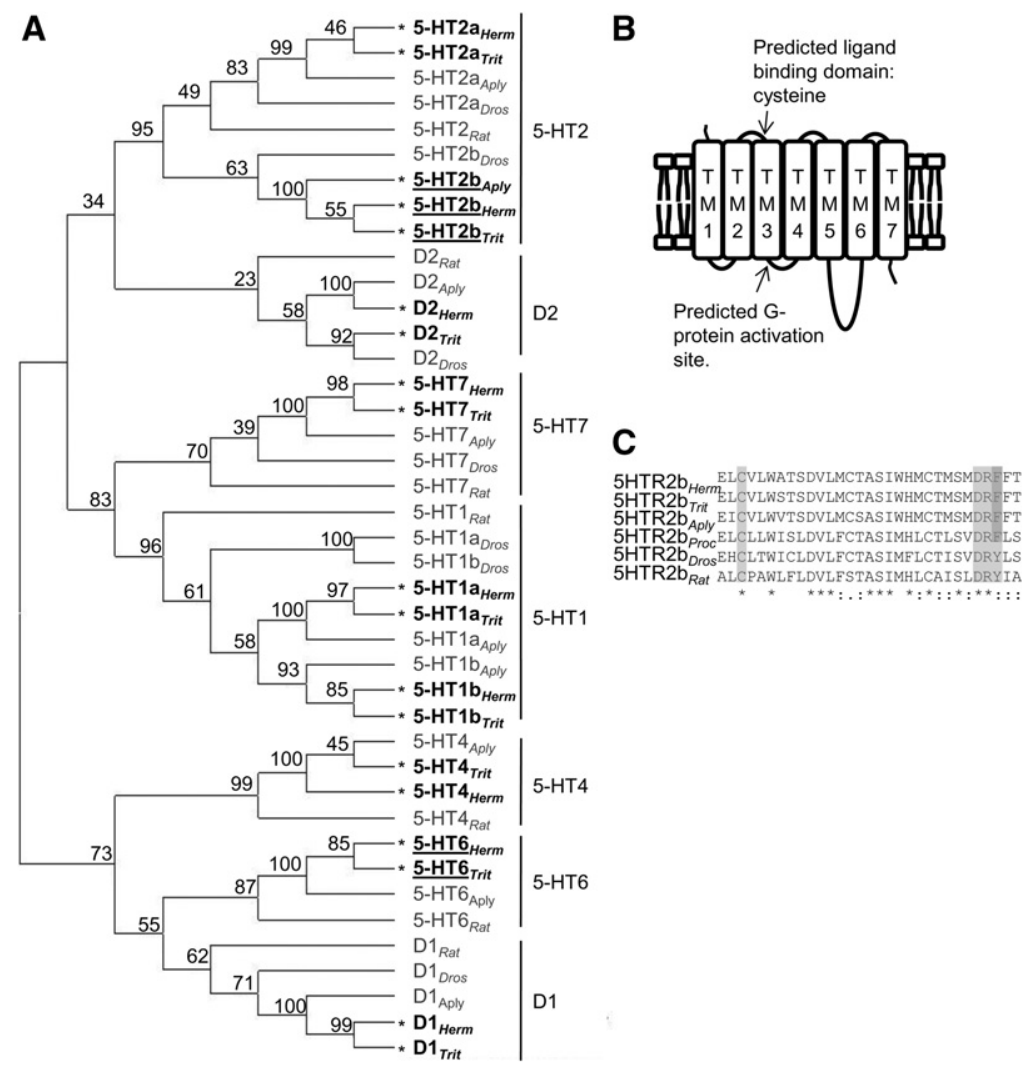

Figure 1. 5-HT receptor phylogenetic relationships. (A) Maximum likelihood phylogenetic tree showing relationships between receptor subtypes. Bootstrap values are shown for each node. Subunits were aligned using transmembrane regions $1-5$ and $6-7$, or $1-5$ only for fragmented receptor subtypes. Receptors that were identified from Hermissenda or Tritonia are shown in bold and marked with an asterisk. Receptors that were identified as novel in molluscs (5-HT2b) or invertebrates (5-HT6) are shown in bold and underlined text. The dopamine receptors D1 and D2 are also shown, as they are part of the superfamily of aminergic receptors. (B) 5-HT receptor model showing seven transmembrane domain regions with location of predicted ligand binding site and G-protein activation site shown. (C) $5-\mathrm{HT} 2 \mathrm{~b}$ ClustalW alignment shows location of predicted ligand binding conserved cysteine residue, shaded in light gray, and predicted G-protein activation site shaded in light gray for DRY motif, dark gray for DRF motif. Species abbreviations: Hermissenda crassicornis (Herm), Tritonia diomedea (Trit), Aplysia californica $($ Aply), Drosophila melanogaster (Dros), Rattus norvegicus (Rat), Procambarus clarkii (Proc).

and $2 \mathrm{~b}$ genes were more highly expressed in whole-body cDNA compared with brain cDNA. This indicates that while 5-HT2a and 2b are expressed at very low levels in the Hermissenda brain, they are expressed at higher levels elsewhere in the body. RSEM (Li and Dewey 2011), a program that estimates relative abundance of genes in the transcriptome by providing transcripts per million (TPM) values, indicated that these genes were in very low abundance in the brain (see RSEM Relative Transcriptome Abundance, Supplemental Table S1; Tritonia RSEM abundance not shown). To verify the RSEM data, we compared 5-HT2 $\mathrm{a}_{\text {Herm }}$ (Supplemental Table S1, TPM 3.38) with the Hermissenda 5-HT transporter (Supplemental Table S1, TPM 166.17), and the Hermissenda Pedal Peptide 3 Precursor (contig ID comp64571_c0_seq1, TPM 1264.32). Using absolute real-time quantitative PCR (qPCR), we found that there was a strong correlation between the RSEM-predicted expression level in the transcriptome and the amount measured from whole-brain tissue by qPCR (Supplemental Fig. S4).

GABA is another neurotransmitter that modulates light-movement paired learning (Schultz and Clark 1997; Blackwell 2002). No GABA receptor genes had been previously described from Hermissenda. Metabotropic GABA type B receptor subunits 1 (GABA-BR1) and 2 (GABA-BR2) were predicted from the Aplysia genome (XM_005092746.1 and XM_005109637.1) and a GABA-BR1 subunit gene was described in the Tritonia brain transcriptome (Senatore et al. 2015). The BR1 and BR2 subunits most likely function as heterodimers, as they do in other species (Kammerer et al. 1999). A GABA-BR3 subunit was identified in Drosophila (Mezler et al. 2001), but had

the arthropod 5-HT2b gene than with the molluscan 5-HT2a gene. Note that although the 5 -HT2 receptors in invertebrates and vertebrates form a cluster, the nomenclature for 5-HT2 subtypes in vertebrates and invertebrates does not correspond because the genes diverged in each group after the protostome/ deuterostome split (Peroutka and Howell 1994).

Interestingly the crustacean 5 -HT2b protein contains a highly derived DRF motif, which causes constitutive activity of the associated G-protein activation site (Clark et al. 2004), instead of a DRY-motif G-protein activation site, which is more common in 5-HT receptors. The DRF-motif was also found in the molluscan 5-HT2b predicted proteins (Fig. 1C), which might be further indication that the 5-HT2b gene evolved before the lophotrocozoan-ecdysozoan split. Alternatively, it could indicate parallel evolution of G-protein activation site motifs. The identification of a 5-HT2b gene may provide useful information about the functions of 5-HT receptors in molluscan learning.

We PCR amplified, cloned, and sequenced 5-HT2a and 5-HT2b genes from cDNA generated from Hermissenda and Tritonia brains and from Hermissenda whole-body cDNA. In Hermissenda, the initial PCR amplification indicated that 5-HT2a not been previously identified in any molluscs. We identified GABA-BRs in the Hermissenda transcriptome, and verified sequences by tBLASTx or BLASTx against NCBI and UniProt/SwissProt databases. GABA-BR1 genes were identified in the Hermissenda, as well as the Aplysia brain transcriptomes. GABA-BR2 genes were identified in Hermissenda, Tritonia, and Aplysia transcriptomes. A GABA-BR3 subunit was also identified in the brain transcriptomes of each of the three species, which aligns more closely with the Drosophila GABA-BR3 subunit than it does with molluscan GABA-BR1 or GABA-BR2 subunits (Fig. 2). The function of the GABA-BR3 gene in Drosophila is unknown, however (Mezler et al. 2001), so we cannot predict whether this gene is involved in molluscan learning, although the newly identified GABA-BR $1_{\text {Herm }}$ and GABA-BR2 $2_{\text {Herm }}$ genes most likely play roles in mediating Hermissenda lightvestibular stimulation pairing.

Adenylyl cyclase (AC) is part of the second messenger system required for memory formation, and is involved in changes within the presynaptic hair cells that occur during Hermissenda associative learning (Tamse et al. 2003). In Aplysia, four AC genes had been previously identified from families known as AC1, AC5/6, AC2 $/ 4 / 7$, and AC9 (Sossin and Abrams 2009; Lin et al. 2010). Of 

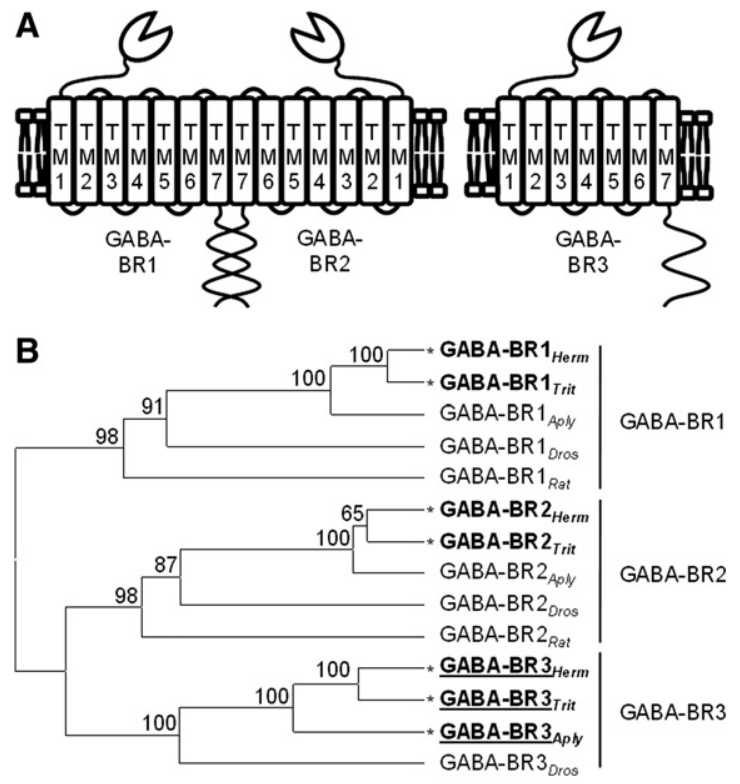

Figure 2. Phylogenetic relationships between GABA-B receptor subunits. (A) Diagram of GABA-B receptor subunits, with predicted GABA-BR3 ${ }_{\text {Herm. }}$. The seven transmembrane domains, heterodimeric carboxy terminals, and venus-flytrap motif amino terminals are shown. (B) Maximum likelihood phylogenic tree of GABA-B receptor subunits. Subunits were aligned using transmembrane regions 1-7. Bootstrap values are shown for each node. Receptor subunits identified for Hermissenda, Tritonia, or Aplysia are shown in bold and marked with an asterisk. Receptor subunits that were identified as novel in molluscs are shown in bold and underlined text. Species abbreviations: Hermissenda crassicornis (Herm), Tritonia diomedea (Trit), Aplysia californica (Aply), Drosophila melanogaster (Dros), Rattus norvegicus (Rat).

those genes, the AC1 family is calcium-sensitive, and is involved in learning (Abrams 1985). Orthologs of each of the four AC genes were identified in the Hermissenda and Tritonia transcriptomes (Fig. 3). The Hermissenda and Tritonia AC genes were fragmented into several contigs, which spanned portions of the $\mathrm{C} 1$ region or transmembrane spanning domains. It may be that the transcriptome assembly did not detect the entire genes, since it would be unlikely that all known gene orthologs are truncated in these species. The fragmentation of the molluscan genes may have caused the resulting phylogenetic tree in Figure 3 to indicate that Drosophila and rat AC genes are more closely related to one another than they actually are. Hermissenda and Tritonia AC genes were named here using the naming convention previously published for Aplysia (Sossin and Abrams 2009).

In addition to the four previously identified AC genes, a fifth family, known as AC3, has been predicted from Aplysia genomic DNA (NCBI reference XM_005108194.1) and was also identified in the Lottia gigantea genome (Sossin and Abrams 2009), but had not been identified as being expressed as mRNA in molluscs. The Hermissenda transcriptome contained an ortholog of the AC3 gene. A similar gene was also found in the Aplysia transcriptome, although no AC3 gene was found in the Tritonia transcriptome (Fig. 3). Tritonia's missing AC3 gene may be explained by an incomplete transcriptome, but could also be because the ortholog was lost in that species.

In conclusion, we have sequenced and de novo assembled the Hermissenda crassicornis brain transcriptome, generating 165,743 total transcripts. Using BLAST annotations of the assembled transcriptome and its TransDecoder-predicted proteins, the Hermissenda transcriptome was found to be highly similar in gene content to other published transcriptomes. BLAST searches against SwissProt and RefSeq, in combination with BLAST2GO annotation, revealed a large number of transcripts that are likely orthologs of previously published genes. Although a portion of the transcripts revealed fragmented genes, TransDecoder analysis showed that at least $50 \%$ of predicted proteins greater than 300 amino acids in length were full-length proteins. As assembly methods continue to improve, greater assembly coverage may be attained using this transcriptome, therefore we have published the raw transcriptome data to NCBI BioProject PRJNA270545, and have published a BLAST-searchable assembly at http:// neuroscience.gsu.edu/blast/.

To illustrate its power as a tool for learning and memory research, we selected genes that produce proteins involved in learning and mined their orthologs from the Hermissenda transcriptome. We identified 95 genes by BLAST analysis as orthologs of learning-related genes. Of those, we highlighted three families of genes by phylogenetic analysis: 5 -HT receptors, GABA-B receptors, and ACs. Within each gene family, one or more genes were identified that are novel for molluscs. Their identification indicates that the Hermissenda transcriptome is not only able to identify orthologs of Aplysia learning and memory genes, but can advance the field of molluscan learning and memory studies by identifying genes previously not described in molluscs. Gastropod molluscs are useful research subjects because their brains contain relatively simple neural circuits composed of identifiable neurons, but their value as a genetic research model has

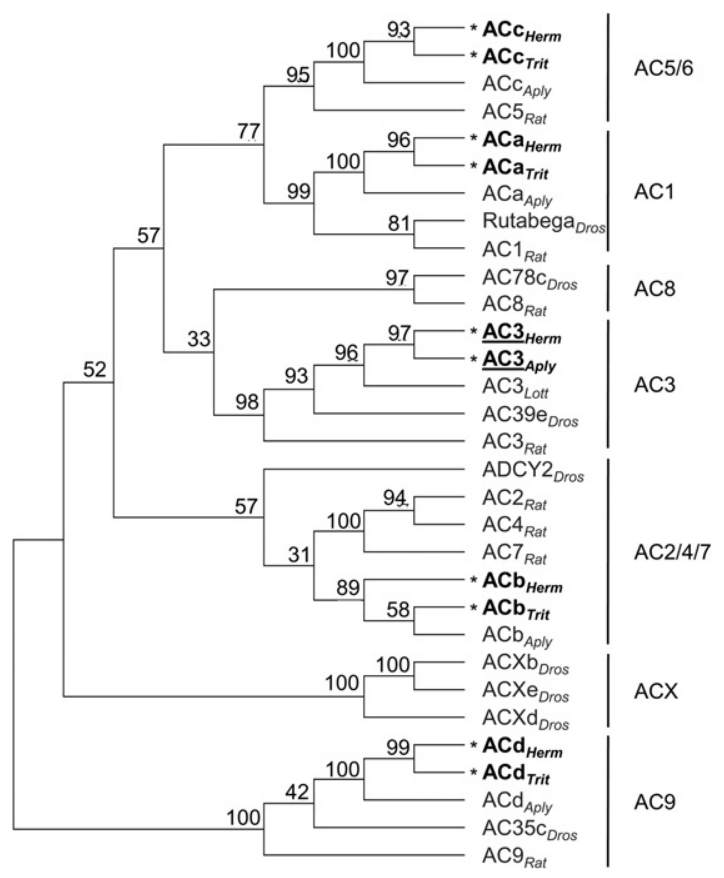

Figure 3. Phylogenetic relationships between adenylyl cyclase (AC) genes. Maximum likelihood phylogenetic tree showing relationship between AC families. Bootstrap values are shown for each node. Genes identified as novel for Hermissenda and Tritonia are shown in bold and marked with an asterisk. Genes that were identified as novel in gastropods are shown in bold underlined text. Fragments of the Hermissenda and Tritonia genes, and the Aplysia AC3 gene, were identified from their transcriptomes and aligned against full-length orthologs from Aplysia, Drosophila, and rat to determine their orientation. Most fragments aligned to the $\mathrm{C} 1$ region of the gene or to one of the transmembrane domain spanning regions. For previously published species, full-length proteins were used in the alignment. Species abbreviations: Hermissenda crassicornis (Herm), Tritonia diomedea (Trit), Aplysia californica (Aply), Lottia gigantea (Lott), Drosophila melanogaster(Dros), Rattus norvegicus (Rat). 
been limited to a few species. The Hermissenda transcriptome will increase knowledge of the neural correlates of learning by providing new genetic information and a basis for gene manipulation that was not previously possible, therefore making it a beneficial tool for learning and other molluscan research in the future.

\section{Acknowledgments}

This work was supported by NSF- IOS-1120950.

\section{References}

Abrams TW. 1985. Activity-dependent presynaptic facilitation: an associative mechanism in Aplysia. Cell Mol Neurobiol 5: 123-145.

Alkon DL. 1980. Membrane depolarization accumulates during acquisition of an associative behavioral change. Science 210: $1375-1376$.

Alkon DL, Anderson MJ, Kuzirian AJ, Rogers DF, Fass DM, Collin C, Nelson TJ, Kapetanovic IM, Matzel LD. 1993. GABA-mediated synaptic interaction between the visual and vestibular pathways of Hermissenda. J Neurochem 61: 556-566

Ashburner M, Ball CA, Blake JA, Botstein D, Butler H, Cherry JM, Davis AP, Dolinski K, Dwight SS, Eppig JT, et al. 2000. Gene ontology: tool for the unification of biology. The Gene Ontology Consortium. Nat Genet 25: $25-29$.

Blackwell KT. 2002. Calcium waves and closure of potassium channels in response to GABA stimulation in Hermissenda type B photoreceptors. $J$ Neurophysiol 87: 776-792.

Blackwell KT. 2006. Subcellular, cellular, and circuit mechanisms underlying classical conditioning in Hermissenda crassicornis. Anat Rec B New Anat 289: 25-37.

Blackwell K, Farley J. 2008. Hermissenda. Scholarpedia 3: 4090.

Bouetard A, Noirot C, Besnard AL, Bouchez O, Choisne D, Robe E, Klopp C, Lagadic L, Coutellec MA. 2012. Pyrosequencing-based transcriptomic resources in the pond snail Lymnaea stagnalis, with a focus on genes involved in molecular response to diquat-induced stress. Ecotoxicology 21: $2222-2234$

Britton G, Farley J. 1999. Behavioral and neural bases of noncoincidence learning in Hermissenda. J Neurosci 19: 9126-9132.

Cavallo JS, Hamilton BN, Farley J. 2014. In vitro extinction learning in Hermissenda: involvement of conditioned inhibition molecules. Front Behav Neurosci 8: 354.

Choi SL, Lee YS, Rim YS, Kim TH, Moroz LL, Kandel ER, Bhak J, Kaang BK. 2010. Differential evolutionary rates of neuronal transcriptome in Aplysia kurodai and Aplysia californica as a tool for gene mining. $J$ Neurogenet 24: 75-82.

Clark MC, Dever TE, Dever JJ, Xu P, Rehder V, Sosa MA, Baro DJ. 2004. Arthropod 5-HT2 receptors: a neurohormonal receptor in decapod crustaceans that displays agonist independent activity resulting from an evolutionary alteration to the DRY motif. J. Neurosci 24: 3421-3435

Conesa A, Götz S, García-Gómez JM, Terol J, Talón M, Robles M. 2005. BLAST2GO: a universal tool for annotation, visualization and analysis in functional genomics research. Bioinformatics 21: 3674-3676.

Crow TJ, Alkon DL. 1978. Retention of an associative behavioral change in Hermissenda. Science 201: 1239-1241.

Crow TJ, Alkon DL. 1980. Associative behavioral modification in Hermissenda: cellular correlates. Science 209: 412-414.

Crow T, Tian LM. 2004. Statocyst hair cell activation of identified interneurons and foot contraction motor neurons in Hermissenda. J Neurophysiol 91: 2874-2883.

Crow T, Siddiqi V, Dash PK. 1997. Long-term enhancement but not short-term in Hermissenda is dependent upon mRNA synthesis. Neurobiol Learn Mem 68: 343-350.

Crow T, Jin N, Tian LM. 2013. Network interneurons underlying ciliary locomotion in Hermissenda. I Neurophys 109: 640-648.

Fiedler TJ, Hudder A, McKay SJ, Shivkumar S, Capo TR, Schmale MC, Walsh PJ. 2010. The transcriptome of the early life history stages of the California Sea Hare Aplysia californica. Comp Biochem Physiol Part D Genomics Proteomics 5: 165-170.

Haas BJ, Papanicolaou A, Yassour M, Grabherr M, Blood PD, Bowden J, Couger MB, Eccles D, Li B, Lieber M, et al. 2013. De novo transcript sequence reconstruction from RNA-seq using the Trinity platform for reference generation and analysis. Nat Protoc 8: 1494-1512.

Heyland A, Vue Z, Voolstra CR, Medina M, Moroz LL. 2011. Developmental transcriptome of Aplysia californica. J Exp Zool B Mol Dev Evol 15: $113-134$.
Jin N, Crow T. 2011. Serotonin regulates voltage-dependent currents in type I(e(A)) and I(i) interneurons of Hermissenda. J Neurophys 106: 2557-2569.

Jin N, Tian LM, Crow T. 2009. 5-HT and GABA modulate intrinsic excitability of type I interneurons in Hermissenda. J Neurophys 102: $2825-2833$.

Joshi NA, Fass JN. 2011. Sickle: a sliding-window, adaptive, quality-based trimming tool for FastQ files (Version 1.33) [Software]. https://github .com/najoshi/sickle.

Kammerer RA, Frank S, Schulthess T, Landwehr R, Lustig A, Engel J. 1999. Heterodimerization of a functional GABAB receptor is mediated by parallel coiled-coil $\alpha$-helices. Biochemistry 38: 13263-13269.

Kanehisa M, Goto S. 2000. KEGG: Kyoto encyclopedia of genes and genomes. Nucleic Acids Res 28: 27-30.

Lee YS, Choi SL, Kim TH, Lee JA, Kim HK, Kim H, Jang DJ, Lee JJ, Lee S, Sin GS, et al. 2008. Transcriptome analysis and identification of regulators for long-term plasticity in Aplysia kurodai. Proc Natl Acad Sci 105: $18602-18607$.

Li B, Dewey CN. 2011. RSEM: accurate transcript quantification from RNA-Seq data with or without a reference genome. BMC Bioinformatics 12: 323.

Lillvis JL, Katz PS. 2013. Parallel evolution of serotonergic neuromodulation underlies independent evolution of rhythmic motor behavior. J Neurosci 33: 2709-2717.

Lillvis J, Gunaratne C, Katz PS. 2012. Neurochemical and neuroanatomical identification of central pattern generator neuron homologues in Nudipleura molluscs. PLoS One 7: e31737.

Lin AH, Cohen JE, Wan Q, Niu K, Shrestha P, Bernstein SL, Abrams TW. 2010. Serotonin stimulation of cAMP-dependent plasticity in Aplysia sensory neurons is mediated by calmodulin-sensitive adenylyl cyclase. Proc Natl Acad Sci 107: 15607-15612.

Mezler M, Müller T, Raming K. 2001. Cloning and functional expression of GABAB receptors from Drosophila. Eur J Neurosci 13: 477-486.

Moroz LL, Edwards JR, Puthanveettil SV, Kohn AB, Ha T, Heyland A, Knudsen B, Sahni A, Yu F, Liu L, et al. 2006. Neuronal transcriptome of Aplysia: neuronal compartments and circuitry. Cell 127: 1453-1467.

Mustard JA, Beggs KT, Mercer AR. 2005. Molecular biology of the invertebrate dopamine receptors. Arch Insect Biochem Physiol 59: $103-117$.

Nagakura I, Dunn TW, Farah CA, Heppner A, Li FF, Sossin WS. 2010. Regulation of protein kinase C Apl II by serotonin receptors in Aplysia. J. Neurochem 115: 994-1006.

Nelson TJ, Alkon DL. 1988. Prolonged RNA changes in the Hermissenda eye induced by classical conditioning. Proc Natl Acad Sci 85: $7800-7804$.

Nesse WH, Clark GA. 2010. Relative spike timing in stochastic oscillator networks of the Hermissenda eye. Biol Cybern 102: 389-412.

Newcomb JM, Sakurai A, Lillvis JL, Gunaratne CA, Katz PS. 2012. Homology and homoplasy of swimming behaviors and neural circuits in the Nudipleura (Mollusca, Gastropoda, Opisthobranchia). Proc Natl Acad Sci 109: 10669-10676.

Peroutka SJ, Howell TA. 1994. The molecular evolution of G-protein coupled receptors: focus on 5-hydroxytryptamine receptors. Neuropharmacology 33: 319-324.

Sadamoto H, Takahashi H, Okada T, Kenmoku H, Toyota M, Asakawa Y. 2012. De novo sequencing and transcriptome analysis of the central nervous system of mollusc Lymnaea stagnalis by deep RNA sequencing. PLoS One 7: e42546.

Schultz LM, Clark GA. 1997. GABA-induced synaptic facilitation at type B to A photoreceptor connections in Hermissenda. Brain Res Bull 42: 377-383.

Senatore A, Edirisinghe N, Katz PS. 2015. Deep RNA sequencing of the Tritonia diomedea central nervous system provides access to gene homologues for neuronal excitability and synaptic transmission. PLoS One 10: e0123514.

Sossin WS, Abrams TW. 2009. Evolutionary conservation of the signaling proteins upstream of cyclic amp-dependent kinase and protein kinase c in gastropod mollusks. Brain Behav Evol 74: 191-205.

Spielman SJ, Kumar K, Wilke CO. 2015. Comprehensive, structurally-informed alignment and phylogeny of vertebrate biogenic amine receptors. PeerJ 17: e773.

Tamse CT, Xu Y, Song H, Nie L, Yamoah EN. 2003. Protein kinase a mediates voltage-dependent facilitation of $\mathrm{ca}^{2+}$ current in presynaptic hair cells in Hermissenda crassicornis. J Neurophysiol 89: 1718-1726.

Received January 14, 2015; accepted in revised form September 28, 2015. 


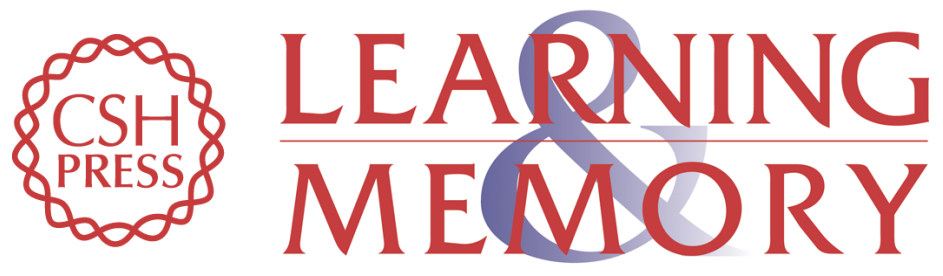

\section{Identification of genes related to learning and memory in the brain transcriptome of the mollusc, Hermissenda crassicornis}

Arianna N. Tamvacakis, Adriano Senatore and Paul S. Katz

Learn. Mem. 2015, 22:

Access the most recent version at doi:10.1101/Im.038158.115

\section{Supplemental http://learnmem.cshlp.org/content/suppl/2015/11/11/22.12.617.DC1 Material}

References This article cites 44 articles, 10 of which can be accessed free at: http://learnmem.cshlp.org/content/22/12/617.full.html\#ref-list-1

Creative This article is distributed exclusively by Cold Spring Harbor Laboratory Press for the Commons first 12 months after the full-issue publication date (see

License http://learnmem.cshlp.org/site/misc/terms.xhtml). After 12 months, it is available under a Creative Commons License (Attribution-NonCommercial 4.0 International), as described at http://creativecommons.org/licenses/by-nc/4.0/.

Email Alerting Receive free email alerts when new articles cite this article - sign up in the box at the Service top right corner of the article or click here. 